\title{
New Insights in the Formation of Deoxynucleoside Adducts with the Heterocyclic Aromatic Amines PhIP and IQ by Means of Ion Trap $\mathbf{M S}^{\mathbf{n}}$ and Accurate Mass Measurement of Fragment Ions
}

\author{
Emilien L. Jamin, ${ }^{a}$ Delphine Arquier, ${ }^{\text {a }}$ Cécile Canlet, ${ }^{a}$ Estelle Rathahao, ${ }^{b}$ \\ Jacques Tulliez, ${ }^{\mathrm{a}}$ and Laurent Debrauwer ${ }^{\mathrm{a}}$ \\ ${ }^{a}$ UMR 1089 Xenobiotiques INRA-ENVT, 180 Chemin de Tournefeuille, Toulouse, France \\ b INRA/INA P-G, Laboratoire de Chimie Analytique UMR 0214-AQA, AgroParisTech, Paris, France
}

\begin{abstract}
The formation of adducts by reaction of active metabolites of two heterocyclic aromatic amines (NHOH-PhIP and $\mathrm{NHOH}-\mathrm{IQ}$ ) at nucleophilic sites of deoxynucleosides has been studied by LC-MS $^{\mathrm{n}}$ analyses of the obtained reaction mixtures. Sequential MS ${ }^{3}$ experiments were carried out on an ion trap mass spectrometer to gain extensive structural information on each adduct detected in the first MS step. Attribution of ions was supported by accurate mass measurements performed on an Orbitrap mass analyzer. Particular attention was given to ions diagnostic of the linking between the heterocyclic aromatic amine (HAA) and the deoxynucleoside. By this way, the structures of five adducts have been characterized in this study, among which two are new compounds: dG-N7-IQ and dA-N $\mathrm{N}^{6} \mathrm{IQ}$. No depurinating adduct was found in the reactions investigated therein. As expected, the $\mathrm{C} 8$ and $\mathrm{N}^{2}$ atoms of $\mathrm{dG}$ were found as the most reactive sites of deoxynucleosides, resulting in the formation of two different adducts with IQ and one adduct with PhIP. An unusual non-depurinating dG-N7-IQ adduct has been characterized and a mechanism is proposed for its formation on the basis of the reactivity of arylamines. A dA-N ${ }^{6}-\mathrm{IQ}$ adduct has been identified for the first time in this work, showing that HAAs can generate DNA adducts with bases other than dG. (J Am Soc Mass Spectrom 2007, 18, 2107-2118) @ 2007 American Society for Mass Spectrometry
\end{abstract}

$\mathrm{A}$ mong all possible DNA modifications inducing mutations and cancer initiations, the formation of covalent adducts with DNA bases represents one of the most significant [1, 2]. For some genotoxic substances, such as heterocyclic aromatic amines (HAAs), the formation of DNA adducts is now the only way to explain their mutagenic and carcinogenic properties observed in laboratory animals [3, 4]. HAAs are produced during the cooking of meats from proteins, amino acids, creatin(in)e, and carbohydrates either by radical mechanisms or by the Maillard reaction [5, 6]. Indeed, HAAs have been characterized in all kinds of meats cooked by most heating processes and human consumers are therefore daily exposed to these genotoxic compounds via their diet at estimated amounts around $15 \mu \mathrm{g}$ per person and per day [7]. The most abundant HAA, 2-amino-6-phenyl-1-methylimidazo $[4,5-b]$ pyridine $(\mathrm{PhIP})$, is produced at concentrations of dozens of nanograms per gram of cooked meats,

Address reprint requests to Dr. Laurent Debrauwer, INRA, Laboratoire des Xenobiotiques, BP 3, Chemin de Tournefeuille, 31931 Toulouse Cedex 9, France. E-mail: laurent.debrauwer@toulouse.inra.fr whereas other HAAs are formed at concentrations of only few ng $\mathrm{g}^{-1}$ or less [8]. Following their food intake absorption, HAAs are metabolized in liver by phase I cytochrome P450 enzymes (CYP1A1, CYP1A2, etc.) into $N$-hydroxy-HAAs. If these metabolites are not deactivated, phase II metabolic enzymes, such as $N$ acetyltransferase, can generate esters of $N$-hydroxyHAAs derivatives. Finally, the heterolytic cleavage of the $\mathrm{N}-\mathrm{O}$ bond of these latter produces arylnitrenium ions, which are highly electrophilic species able to react with nucleophilic sites of cellular macromolecules (proteins, DNA) and form covalent adducts $[9,10]$.

Numerous analytical techniques have been used to characterize DNA adducts like ${ }^{32} \mathrm{P}$-postlabeling, immunochemical methods, fluorescence, or mass spectrometry [11]. Although mass spectrometry is relatively less sensitive than ${ }^{32} \mathrm{P}$-postlabeling for DNA adducts detection, this analytical method is more selective, quantitative [12] and, above all, allows the structural determination of adducts. Most of the techniques cited earlier have been used to characterize adducts formed between DNA and HAAs. Major HAA-DNA adducts thus characterized involved the $\mathrm{C} 8$ carbon atom of guanine 
linked to the primary amine function of various HAAs, forming dG-C8-HAA adducts [13]. Besides these major adducts, minor ones have also been described between 2-amino-3-methyl-3H-imidazo[4,5-f]quinoline (IQ) or 2amino-3,8-dimethylimidazo[4,5-flquinoxaline (MeIQx) and the primary amine function of guanine, thus constituting dG-N ${ }^{2}$-HAA adducts [13].

Powerful analytical methods mainly based on capillary high-performance liquid chromatography (HPLC) or capillary electrophoresis coupled to mass spectrometry have been developed for the characterization of these structurally known adducts formed in vivo. However, although analytical systems have been dramatically improved, no work has revisited the adduct formation between HAAs and deoxynucleosides in the past decade [14]. Therefore, a systematic investigation on HAA-deoxynucleoside adduct formation was performed in this study, by assessing the reactivity of the four deoxynucleosides ( $\mathrm{dG}, \mathrm{dA}, \mathrm{dC}$, and $\mathrm{dT}$ ) with PhIP and IQ, whose structures are reported in Figure 1. Syntheses protocols were achieved as much as possible under conditions similar to the biological environment to produce realistic adducts. Crude reaction solutions were analyzed by mass spectrometry coupled to HPLC to detect HAA adducts and characterize their structures using ion trap $\mathrm{MS}^{\mathrm{n}}$ sequences as well as accurate mass measurements performed on the various MS stages of the mass analysis. The use of modern mass spectrometric methods provides new data for the characterization of HAA-DNA adducts by allowing the unambiguous assignment of structurally relevant fragment ions. When synthesized amounts of adducts were sufficient, nuclear magnetic resonance (NMR) was used to confirm the structures established by mass spectrometry.

\section{Experimental}

\section{Reagents}

$\mathrm{NO}_{2}$-PhIP and NHOH-IQ were purchased from Toronto Research Chemicals (Toronto, Canada). Deoxynucleosides (dG, dA, dC, and dT), EDTA, Pd/C, and hydrazine came from Aldrich (Saint Quentin Fallavier, France). Acetic anhydride was from Prolabo (Paris, France), $\mathrm{NaH}_{2} \mathrm{PO}_{4}$ and DMSO were from Sigma (Saint Quentin Fallavier), and tetrahydrofuran (THF) was from Acros Organics (Geel, Belgium). HPLC-grade
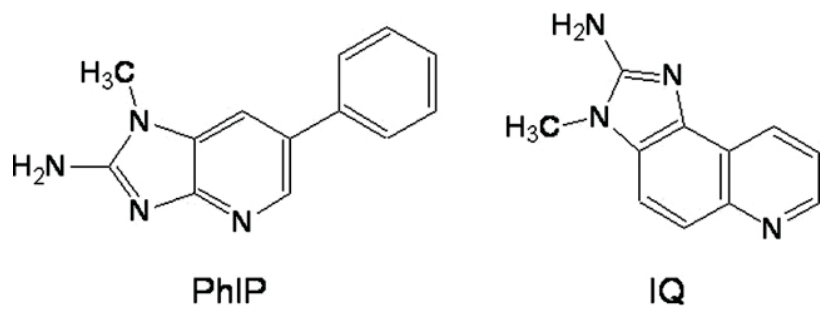

Figure 1. Structures of 2-amino-6-phenyl-1-methylimidazo[4,5- $b]$ pyridine (PhIP) and 2-amino-3-methyl-3H-imidazo[4,5-f]quinoline (IQ). organic solvents were purchased from Scharlau (Barcelona, Spain). Water was obtained by a Milli-Q system (Millipore, Saint Quentin en Yvelines, France). Bond Elut C18 cartridges were from Varian (Les Ulis, France).

\section{Syntheses of Adducts}

Synthesis of PhIP-deoxynucleoside adducts was based on published data [15-17]. Briefly, $0.5 \mathrm{mg}$ of $\mathrm{NO}_{2}-\mathrm{PhIP}$ was dissolved in $2 \mathrm{~mL}$ of anhydrous THF in the presence of $\mathrm{Pd} / \mathrm{C} 10 \%$ (2 mg). The reaction mixture was placed at $0{ }^{\circ} \mathrm{C}$ under magnetic stirring and argon. Hydrazine hydrate $(10 \mu \mathrm{L})$ was added slowly to keep the temperature below $5^{\circ} \mathrm{C}$. After $40 \mathrm{~min}, 10 \mathrm{~mL}$ of cold and purged EDTA (10 mM, pH 4.6) was added to the reaction mixture. $\mathrm{NHOH}-\mathrm{PhIP}$ thus obtained was then purified on a Bond Elut C18 cartridge (200 mg, $3 \mathrm{~mL}$ ) prewashed with one bed volume of $\mathrm{MeOH}$ followed by one bed volume of EDTA buffer (10 mM, pH 4.6). Retained substances were washed with two bed volumes of EDTA buffer, and eluted with one volume of purged DMSO/MeOH 4/1 vol/vol. This solution was directly reacted with acetic anhydride $(11.3 \mu \mathrm{L})$ and allowed to proceed for $10 \mathrm{~min}$ at $0{ }^{\circ} \mathrm{C}$ under argon to produce the AcO-PhIP derivative. Deoxynucleoside $\left(2 \times 10^{-6} \mathrm{~mol}\right)$ dissolved in $10 \mathrm{~mL}$ of purged $\mathrm{NaH}_{2} \mathrm{PO}_{4} /$ EDTA buffer (100 mM/100 $\mu \mathrm{M}, \mathrm{pH}$ 7) was finally added and reaction proceeded for $1 \mathrm{~h}$ at $37^{\circ} \mathrm{C}$ under argon atmosphere. Crude reaction mixtures containing PhIP adducts were stored at $-80^{\circ} \mathrm{C}$ under argon until analysis.

Deoxynucleoside adducts of IQ were prepared according to a previously described protocol [14]. NHydroxy-IQ $(100 \mu \mathrm{g})$ was directly reacted with 2-fold molar excess of deoxynucleosides dissolved in $2.5 \mathrm{~mL}$ of $\mathrm{NaH}_{2} \mathrm{PO}_{4} /$ EDTA $(100 \mathrm{mM} / 100 \mu \mathrm{M}, \mathrm{pH} 7)$ in the presence of acetic anhydride $(1.3 \mu \mathrm{L})$. The reaction mixture was warmed at $37^{\circ} \mathrm{C}$ for $3.5 \mathrm{~h}$ under magnetic stirring and argon. Crude reaction solutions containing IQ adducts were then stored at $-80{ }^{\circ} \mathrm{C}$ under argon until analysis.

\section{HPLC}

LC separation of deoxynucleosides adducts was performed on a Thermo Separation P1500 pump (Thermo Fisher, Les Ulis, France). The LC column used was an Ultrabase C18 $(250 \times 2.1 \mathrm{~mm}, 5 \mu \mathrm{m})$ from SFCC (Eragny, France) and $100 \mu \mathrm{L}$ of crude reaction solutions were injected. Optimal separation was achieved at a flow rate of $0.2 \mathrm{~mL} \mathrm{~min}^{-1}$ using the following mobile phase composition: A: $\mathrm{H}_{2} \mathrm{O} / \mathrm{MeOH} / \mathrm{AcOH} 90 / 10 / 0.2$ $\mathrm{vol} / \mathrm{vol} / \mathrm{vol}$; $\mathrm{B}: \mathrm{H}_{2} \mathrm{O} / \mathrm{MeOH} / \mathrm{AcOH} 10 / 90 / 0.2 \mathrm{vol} /$ vol/vol. The following gradient elution was used for PhIP adducts : $0-3 \mathrm{~min}$ from 0 to $75 \% \mathrm{~B}, 3-16 \mathrm{~min} 75 \%$ B, 16-17 min from 75 to $100 \% \mathrm{~B}, 17-20 \mathrm{~min} 100 \% \mathrm{~B}$. Optimal separation conditions of IQ adducts were: $0-1$ min from 0 to $14 \% \mathrm{~B}, 1-14 \mathrm{~min} 40 \% \mathrm{~B}, 14-15 \mathrm{~min}$ from 40 to $100 \%$ B, $15-24 \min 100 \%$ B. The same LC system 
was used for adduct purification for NMR analyses by collecting the fractions of interest.

\section{Structural Analyses}

The HPLC system was coupled to an LCQ ion trap mass spectrometer (Thermo Fisher) equipped with an electrospray ionization (ESI) source operating in the positive mode and using the following conditions: needle voltage $3.4 \mathrm{kV}$; heated capillary temperature $220^{\circ} \mathrm{C}$; capillary voltage $33 \mathrm{~V}$. Multiple MS experiments $\left(\mathrm{MS}^{\mathrm{n}}\right)$ were achieved using helium as collision gas, an isolation width of precursor ions of $1.5 \mathrm{Da}$, and an activation time of $30 \mathrm{~ms}$. All experiments were carried out under automatic gain conditions.

Accurate mass measurements of fragment ions obtained by $\mathrm{MS}^{3}$ sequential experiments were achieved on the LTQ-Orbitrap mass spectrometer (Thermo Fisher) fitted with an ESI ion source. The following conditions were used: needle voltage $5 \mathrm{kV}$; heated capillary temperature $250{ }^{\circ} \mathrm{C}$; capillary voltage $50 \mathrm{~V}$. $\mathrm{MS}^{\mathrm{n}}$ experiments were achieved using helium as collision gas, an isolation width of precursor ions of $2 \mathrm{Da}$, and an activation time of $30 \mathrm{~ms}$. The Orbitrap mass analyzer works as a detector of the linear ion trap and allows high-resolution $(60,000)$ mass measurements. In the LTQ-Orbitrap mass spectrometer, ions are classically analyzed (trapped, isolated, excited) by the linear ion trap (LTQ), but could be axially ejected and collected in a C-shaped ion trap (C-Trap) to be injected in the Orbitrap. In the Orbitrap, ions assume circular trajectories around a center electrode and their axial oscillations along this center electrode produce a periodic signal on the outer electrodes, which is detected and converted into a spectrum using a Fourier transform algorithm [18].

NMR experiments were performed on a Bruker Avance DRX-600 spectrometer (Wissembourg, France) operating with a proton resonance frequency of 600.13 $\mathrm{MHz}$ and fitted with a triple cryogenic probe ${ }^{1} \mathrm{H}_{-}{ }^{13} \mathrm{C}-{ }^{15} \mathrm{~N}$. Adduct samples were dissolved in $\mathrm{CD}_{3} \mathrm{OD}$ or $\mathrm{CDCl}_{3}$.

\section{Results and Discussion}

\section{PhIP-Deoxynucleoside Adducts}

The first synthesis involving the N-hydroxy-PhIP derivative was performed with guanine to validate our synthesis protocol by producing the already known dG-C8-PhIP adduct [13]. The solution obtained after reaction of $\mathrm{NHOH}-\mathrm{PhIP}$ with $\mathrm{dG}$ was analyzed by LC-MS and the resulting chromatogram, displayed in Figure $2 \mathrm{a}$, showed the occurrence of an ion with an $\mathrm{m} / \mathrm{z}$ ratio of 490 corresponding to that of the expected adduct. The use of the LTQ-Orbitrap mass spectrometer gave an accurate $\mathrm{m} / \mathrm{z}$ ratio corresponding to the molecular formula $\mathrm{C}_{23} \mathrm{H}_{24} \mathrm{O}_{4} \mathrm{~N}_{9}$ in agreement with a dG-PhIP adduct with an error of only $0.31 \mathrm{ppm}$, as indicated in Table 1. The MS/MS experiment performed on this ion showed the formation of a major fragment ion at $\mathrm{m} / \mathrm{z}$ 374 (Figure 2b) whose accurate mass determination gave a signal at $m / z 374.14806$ (Table 1 ). These data are consistent with a neutral loss of deoxyribose, which is a common feature for deoxynucleoside adducts and is usually used for detection of adducts [12, 19]. The production yield of this adduct was about $30 \%$, estimated from peak integration after MS detection of reacted and non-reacted $\mathrm{dG}$, assuming that the respective behaviors of modified and non-modified dG toward electrospray ionization were equivalent.

The structure of this adduct was further investigated by a sequential $\mathrm{MS}^{3}$ experiment built up by selecting as a precursor ion the fragment $[\mathrm{GPhIP}+\mathrm{H}]^{+}$at $\mathrm{m} / \mathrm{z} 374$. Fragment ions observed on the $\mathrm{MS}^{3}$ spectrum presented in Figure $2 \mathrm{c}$ are in good agreement with previously published data on fragmentation of $\mathrm{dG}-\mathrm{C} 8$ adducts

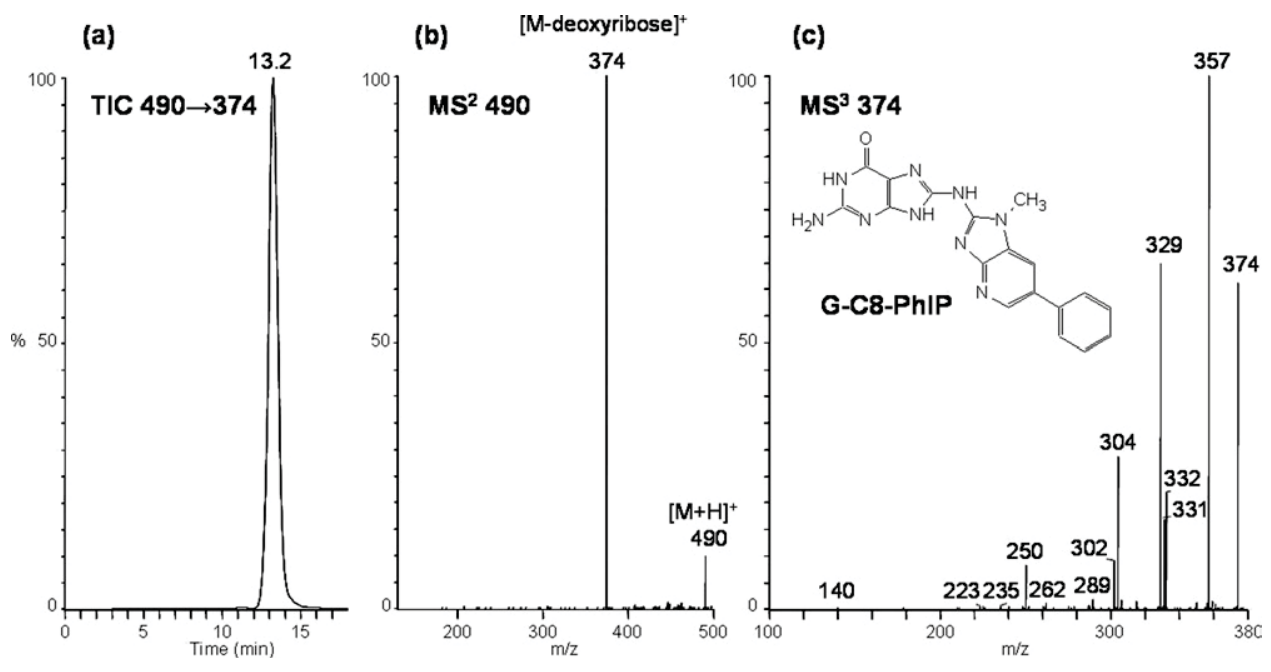

Figure 2. LC-MS/MS of sample obtained by reaction between PhIP and dG: (a) reconstructed ion current chromatogram of $\mathrm{m} / \mathrm{z} 490$ losing a deoxyribose, (b) $\mathrm{MS}^{2}$, and (c) MS $\mathrm{MS}^{3}$ spectra of dG-C8-PhIP. 
Table 1. Accurate mass data from HRMS ${ }^{n}$ analyses of dG-C8-PhIP

\begin{tabular}{|c|c|c|c|c|}
\hline Measured mass & Attribution & Molecular formula & Theoretical mass & Delta (ppm) \\
\hline 490.19528 & {$[\mathrm{dGPhIP}+\mathrm{H}]^{+}$} & $\mathrm{C}_{23} \mathrm{H}_{24} \mathrm{O}_{4} \mathrm{~N}_{9}$ & 490.19513 & 0.31 \\
\hline 374.14806 & {$[\mathrm{GPhIP}+\mathrm{H}]^{+}$} & $\mathrm{C}_{18} \mathrm{H}_{16} \mathrm{ON}_{9}$ & 374.14778 & 0.75 \\
\hline \multirow[t]{2}{*}{357.12131} & $374-\mathrm{NH}_{3}$ & $\mathrm{C}_{18} \mathrm{H}_{13} \mathrm{ON}_{8}$ & 357.12123 & 0.22 \\
\hline & $374-\mathrm{OH}$ & $\mathrm{C}_{18} \mathrm{H}_{15} \mathrm{~N}_{9}$ & 357.14504 & 66.45 \\
\hline \multirow[t]{4}{*}{332.12620} & $374-\mathrm{CH}_{2} \mathrm{~N}_{2}$ & $\mathrm{C}_{17} \mathrm{H}_{14} \mathrm{ON}_{7}$ & 332.12598 & 0.66 \\
\hline & $374-\mathrm{C}_{2} \mathrm{H}_{2} \mathrm{O}$ & $\mathrm{C}_{16} \mathrm{H}_{14} \mathrm{~N}_{9}$ & 332.13722 & 33.17 \\
\hline & $374-\mathrm{C}_{2} \mathrm{H}_{4} \mathrm{~N}$ & $\mathrm{C}_{16} \mathrm{H}_{12} \mathrm{ON}_{8}$ & 332.11341 & 38.52 \\
\hline & $374-\mathrm{CON}$ & $\mathrm{C}_{17} \mathrm{H}_{16} \mathrm{~N}_{8}$ & 331.14979 & 71.03 \\
\hline \multirow[t]{4}{*}{331.14223} & $374-\mathrm{CHON}$ & $\mathrm{C}_{17} \mathrm{H}_{15} \mathrm{~N}_{8}$ & 331.14197 & 0.79 \\
\hline & $374-\mathrm{C}_{2} \mathrm{H}_{3} \mathrm{O}$ & $\mathrm{C}_{16} \mathrm{H}_{13} \mathrm{~N}_{9}$ & 331.12939 & 38.77 \\
\hline & $374-\mathrm{CH}_{3} \mathrm{~N}_{2}$ & $\mathrm{C}_{17} \mathrm{H}_{13} \mathrm{ON}_{7}$ & 331.11816 & 72.70 \\
\hline & $374-\mathrm{C}_{2} \mathrm{H}_{5} \mathrm{~N}$ & $\mathrm{C}_{16} \mathrm{H}_{11} \mathrm{ON}_{8}$ & 331.10558 & 110.68 \\
\hline \multirow[t]{3}{*}{329.12656} & $374-\mathrm{CH}_{3} \mathrm{ON}$ & $\mathrm{C}_{17} \mathrm{H}_{13} \mathrm{~N}_{8}$ & 329.12632 & 0.73 \\
\hline & $374-\mathrm{CH}_{5} \mathrm{~N}_{2}$ & $\mathrm{C}_{17} \mathrm{H}_{11} \mathrm{ON}_{7}$ & 329.10251 & 73.08 \\
\hline & $374-\mathrm{C}_{2} \mathrm{H}_{7} \mathrm{~N}$ & $\mathrm{C}_{16} \mathrm{H}_{9} \mathrm{ON}_{8}$ & 329.08993 & 111.30 \\
\hline \multirow[t]{6}{*}{304.13128} & $374-\mathrm{C}_{2} \mathrm{H}_{2} \mathrm{ON}_{2}$ & $\mathrm{C}_{16} \mathrm{H}_{14} \mathrm{~N}_{7}$ & 304.13107 & 0.69 \\
\hline & $374-\mathrm{C}_{3} \mathrm{H}_{4} \mathrm{ON}$ & $\mathrm{C}_{15} \mathrm{H}_{12} \mathrm{~N}_{8}$ & 304.11849 & 42.05 \\
\hline & $374-\mathrm{C}_{2} \mathrm{H}_{4} \mathrm{~N}_{3}$ & $\mathrm{C}_{16} \mathrm{H}_{12} \mathrm{ON}_{6}$ & 304.10726 & 78.99 \\
\hline & $374-\mathrm{C}_{4} \mathrm{H}_{6} \mathrm{O}$ & $\mathrm{C}_{14} \mathrm{H}_{10} \mathrm{~N}_{9}$ & 304.10592 & 83.41 \\
\hline & $374-\mathrm{C}_{3} \mathrm{H}_{6} \mathrm{~N}_{2}$ & $\mathrm{C}_{15} \mathrm{H}_{10} \mathrm{ON}_{7}$ & 304.09468 & 120.35 \\
\hline & $374-\mathrm{C}_{4} \mathrm{H}_{8} \mathrm{~N}$ & $\mathrm{C}_{14} \mathrm{H}_{8} \mathrm{ON}_{8}$ & 304.08211 & 161.71 \\
\hline \multirow[t]{4}{*}{302.11566} & $374-\mathrm{C}_{2} \mathrm{H}_{4} \mathrm{ON}_{2}$ & $\mathrm{C}_{16} \mathrm{H}_{12} \mathrm{~N}_{7}$ & 302.11542 & 0.79 \\
\hline & $374-\mathrm{C}_{3} \mathrm{H}_{6} \mathrm{ON}$ & $\mathrm{C}_{15} \mathrm{H}_{10} \mathrm{~N}_{8}$ & 302.10284 & 42.43 \\
\hline & $374-\mathrm{C}_{4} \mathrm{H}_{8} \mathrm{O}$ & $\mathrm{C}_{14} \mathrm{H}_{8} \mathrm{~N}_{9}$ & 302.09027 & 84.06 \\
\hline & $374-\mathrm{C}_{3} \mathrm{H}_{8} \mathrm{~N}_{2}$ & $\mathrm{C}_{15} \mathrm{H}_{8} \mathrm{ON}_{7}$ & 302.07903 & 121.25 \\
\hline 289.12036 & & $\mathrm{C}_{16} \mathrm{H}_{13} \mathrm{~N}_{6}$ & 289.12017 & 0.66 \\
\hline 262.10938 & & $\mathrm{C}_{15} \mathrm{H}_{12} \mathrm{~N}_{5}$ & 262.10927 & 0.42 \\
\hline 250.10924 & & $\mathrm{C}_{14} \mathrm{H}_{12} \mathrm{~N}_{5}$ & 250.10927 & 0.12 \\
\hline 235.09838 & & $\mathrm{C}_{14} \mathrm{H}_{11} \mathrm{~N}_{4}$ & 235.09837 & 0.04 \\
\hline
\end{tabular}

[19-23]. Accurate mass measurements performed on the $\mathrm{MS}^{3}$ fragment ions using the LTQ-Orbitrap hybrid instrument are listed in Table 1 together with various possible isobaric molecular formulas and their corresponding calculated masses, clearly showing the usefulness of accurate mass measurements for the assignment of product ions supported by their most probable elemental composition (low delta). By this way, the first fragment ion observed shows a loss of $17 \mathrm{u}(\mathrm{m} / \mathrm{z} 357$ in Figure 2c), in agreement with the elimination of $\mathrm{NH}_{3}$ likely occurring at the primary amine function of $\mathrm{G}$ or from the intracyclic nitrogen atom at position 1 of guanine [20]. The $m / z 332$ fragment ion can be unambiguously attributed to a loss of $\mathrm{CH}_{2} \mathrm{~N}_{2}$ by the highresolution power of the Orbitrap mass analyzer (see Table 1). Actually, the elimination of all other possible isobaric species corresponding to a loss of $42 \mathrm{u}$ (i.e., $\mathrm{CH}_{2} \mathrm{CO}, \mathrm{C}_{2} \mathrm{H}_{4} \mathrm{~N}$ or $\mathrm{CON}$ ) can be ruled out because the calculated exact mass of their respective resulting fragment ions differ by several dozens ppm from the experimental mass measured at $m / z 332.12620$ (Table 1). Similarly, the accurate mass measurement of the $\mathrm{m} / \mathrm{z}$ 331 fragment ion allows us to rule out a loss of $\mathrm{CH}_{3} \mathrm{~N}_{2}$ or $\mathrm{CH}_{3}+\mathrm{CO}$, whereas it is clearly consistent with a loss of CHNO as reported in Table 1. Accurate mass measurements achieved on $\mathrm{m} / \mathrm{z} 329$ and 304 fragment ions provided evidence of losses of $\mathrm{CH}_{3} \mathrm{ON}$ and $\mathrm{C}_{2} \mathrm{H}_{2} \mathrm{ON}_{2}$, respectively. The loss of $\mathrm{CH}_{3} \mathrm{ON}$ could be explained either by a direct elimination of $\mathrm{H}_{2} \mathrm{~N}-\mathrm{CHO}$ or by consecutive losses of $\mathrm{NH}_{3}$ and $\mathrm{CO}$ [24]. Occurrence of the latter could be further confirmed by a sequential $\mathrm{MS}^{4}$ experiment on the $\mathrm{m} / \mathrm{z} 357$ precursor ion [GPhIP + $\left.\mathrm{H}-\mathrm{NH}_{3}\right]^{+}$, which yielded the $\mathrm{m} / z 329$ ion (data not shown). Similarly, the $\mathrm{MS}^{4}$ spectrum of the $\mathrm{m} / \mathrm{z} 332$ ion displayed a fragment ion at $m / z$ 304, showing that the loss of $\mathrm{C}_{2} \mathrm{H}_{2} \mathrm{ON}_{2}$ corresponded to the consecutive elimination of $\mathrm{CH}_{2} \mathrm{~N}_{2}$ and $\mathrm{CO}$ (data not shown). Table 1 indicates that the $m / z 302$ fragment ion corresponds to a loss of $\mathrm{C}_{2} \mathrm{H}_{4} \mathrm{ON}_{2}$ from the $\mathrm{m} / \mathrm{z} 374$ precursor ion, resulting from a consecutive loss of HCN from the $m / z 329$ ion as confirmed by its $\mathrm{MS}^{5}$ spectrum (data not shown). Finally, the empirical formula of the $m / z 289$ fragment ion determined by accurate mass measurement (Table 1) fits well a structure involving PhIP and the imidazole moiety of guanine. However, all these fragment ions demonstrate only that PhIP is bonded to the imidazole moiety of $\mathrm{dG}$ and do not allow the precise identification of atoms involved in the covalent bond between $\mathrm{dG}$ and PhIP. On the other hand, the following fragment ions provide information about the linking of the deoxynucleoside with the HAA. First, the elemental composition of the $m / z 262$ fragment ion corresponds to $\mathrm{C}_{15} \mathrm{H}_{12} \mathrm{~N}_{5}$ as indicated in Table 1 . This is in agreement with a structure involving PhIP and the C8, N9, and C4 atoms of $\mathrm{dG}$ as proposed in Scheme 1a. The $\mathrm{MS}^{4}$ spectrum of the $m / z 304$ ion actually displayed a fragment ion at $m / z 262$, showing that this latter could originate in the $m / z 304$ ion, and supporting our pro- 
(a)

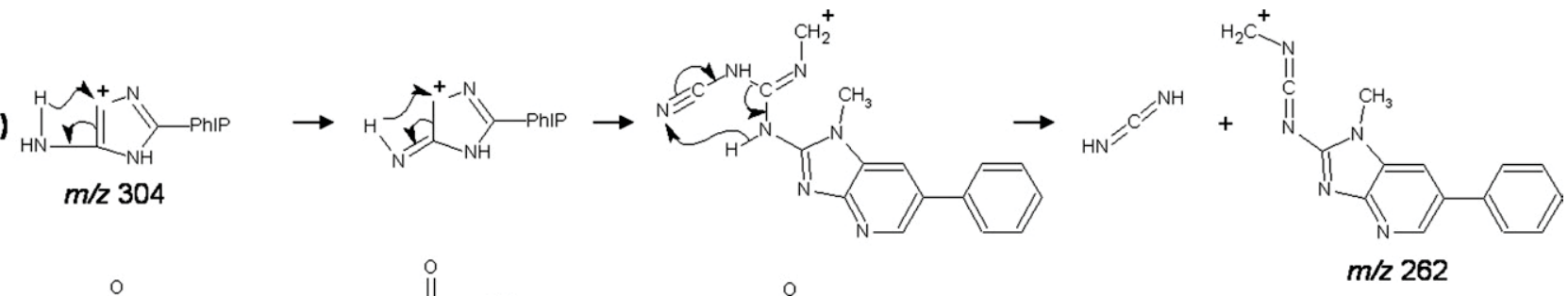

(b)

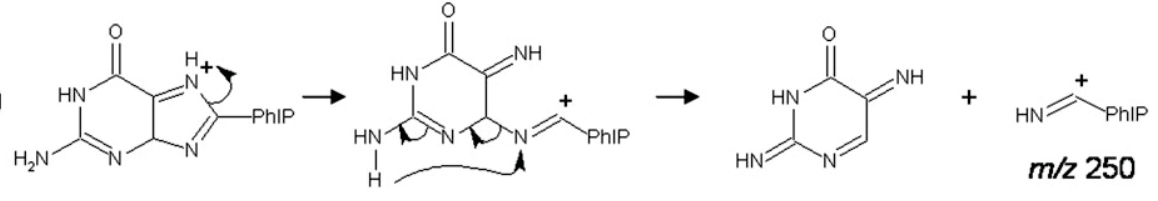

(c)

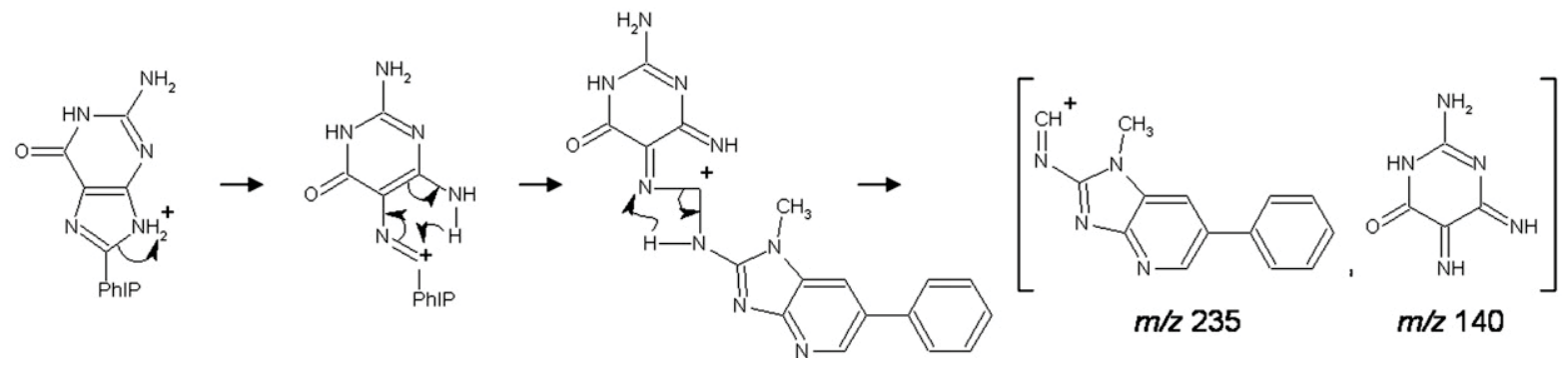

Scheme 1. Formation mechanisms proposed for fragment ions observed in the $\mathrm{MS}^{3}$ spectrum of dG-C8-PhIP.

posal. The molecular formulas obtained for the $\mathrm{m} / \mathrm{z} 250$ and 235 fragment ions (Table 1) agree with the structures presented in Scheme $\mathbf{1 b}$ and $\mathbf{c}$, respectively, and they provide evidence of a linkage between PhIP and the $\mathrm{C} 8$ carbon atom of guanine.

Although some diagnostic ions were obtained for characterizing the involvement of the $\mathrm{C} 8$ atom of guanine in the adduct linking, that is, $m / z 262,250$, and 235 fragment ions, no information was available on the $\mathrm{MS}^{\mathrm{n}}$ spectra concerning the atom of PhIP bonded to the guanine. Therefore, this adduct was analyzed by NMR after purification by chromatography, and chemical shifts displayed in Figure 3 confirmed the structure of dG-C8-PhIP with a covalent bond between G and the primary amine function of PhIP [15]. This could be expected because this latter function was chemically activated in the synthesis protocol. Recently, an additional minor dG-PhIP adduct was detected in vivo from liver and colon of rats exposed to PhIP, and accounted for a few percent of the total amount of dG-PhIP adducts [24]. Although no exact structure could be determined for this adduct, plausible dG-N7-PhIP and isomeric dG-C8-PhIP structures were hypothesized. The occurrence of such an adduct could not be evidenced in this work with PhIP but a similar minor adduct was evidenced in the reaction of $\mathrm{dG}$ with IQ and is discussed later.

No detectable amount of adduct could be evidenced in the LC-MS/MS analysis of reaction mixtures produced from N-hydroxy-PhIP and dA, dC, or dT. Finally, a reaction involving $\mathrm{N}$-hydroxy-PhIP and an equimolar mixture of the four deoxynucleosides was conducted to investigate potential effects of other deoxynucleosides. dG-C8-PhIP amounts obtained by this way were in good agreement with those obtained with $\mathrm{dG}$ alone, demonstrating that the formation of dG-C8-PhIP was not affected by other deoxynucleosides in solution.

\section{IQ-Deoxynucleoside Adducts}

In a similar way as with $\mathrm{PhIP}$, reactions were carried out with $N$-hydroxy-IQ and deoxynucleosides. Thus, the solution obtained after the reaction of $\mathrm{NHOH}-\mathrm{IQ}$ with dG was analyzed by LC-MS ${ }^{\mathrm{n}}$. The chromatogram presented in Figure 4a shows the occurrence of three different compounds at $\mathrm{m} / \mathrm{z} 464$, which could correspond to dG-IQ adducts. Estimated reaction yields were $30 \%$ for the major adduct and $4 \%$ for the most polar adduct. The third adduct eluted at $15.9 \mathrm{~min}$ and corresponded to a new compound formed with a yield $<1 \%$.

The chromatographic peak observed at $\mathrm{RT}=20.2$ min in Figure 4a represents the major and the less polar adduct, which could fit dG-C8-IQ properties [21, 22]. This peak corresponds to an ion with an accurate mass of 464.17904, in agreement with the expected molecular formula of the dG-IQ adduct as indicated in Table 2.

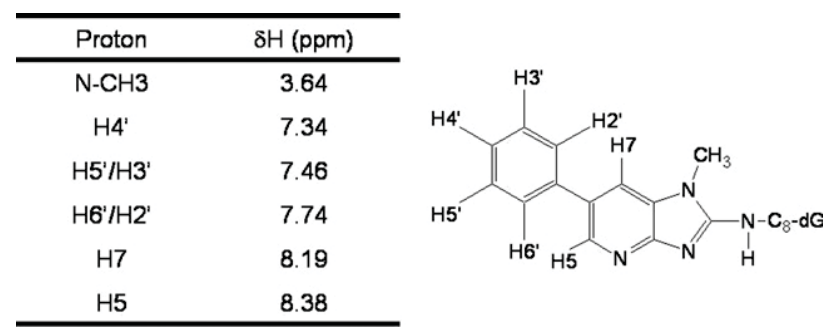

Figure 3. Chemical shifts of dG-C8-PhIP obtained by proton NMR spectrometry. 

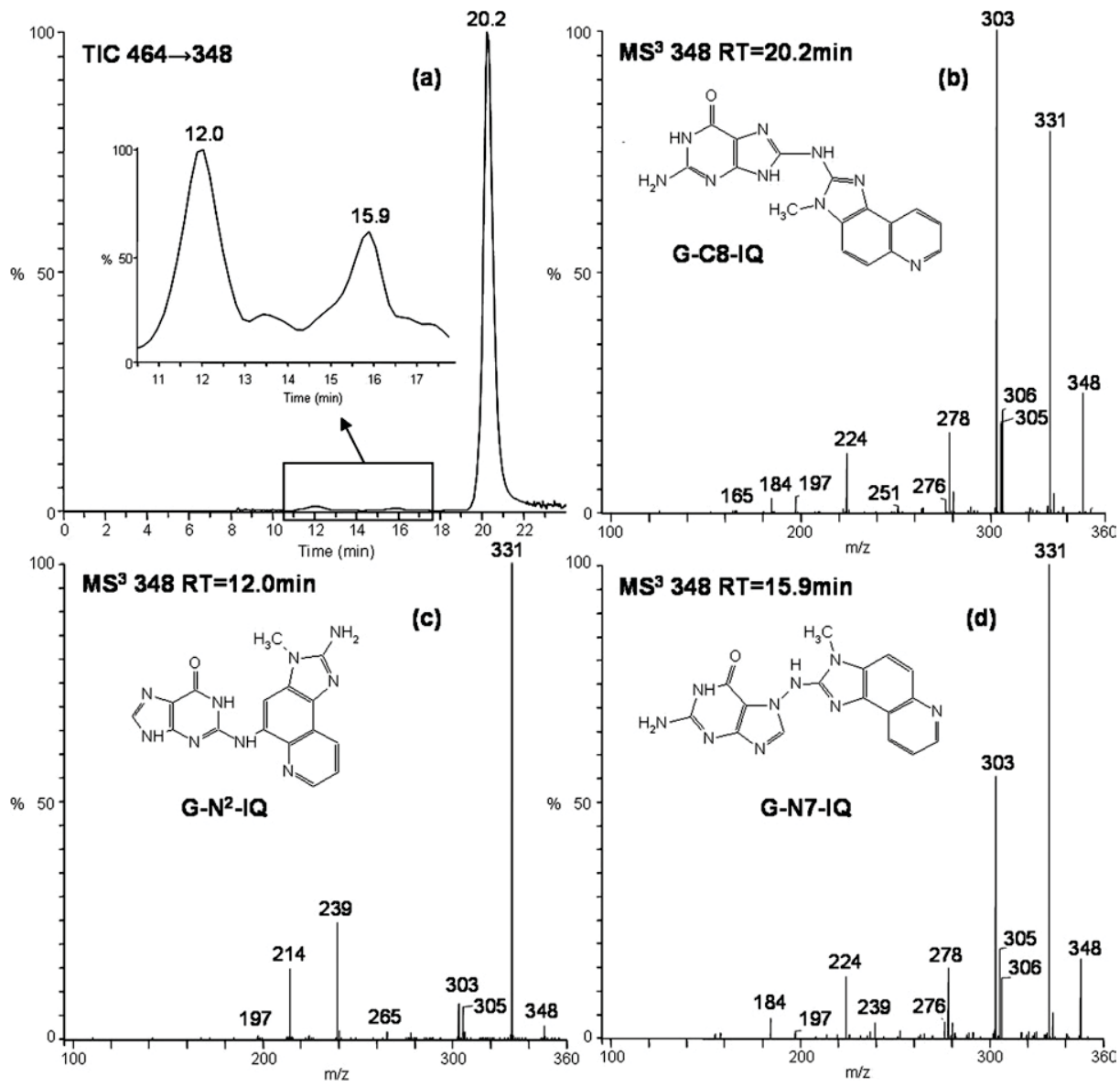

MS $^{3} 348$ RT=15.9min

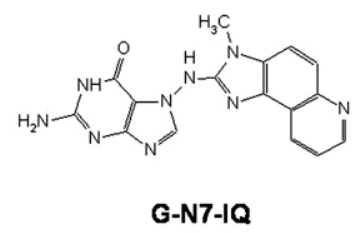

(d)

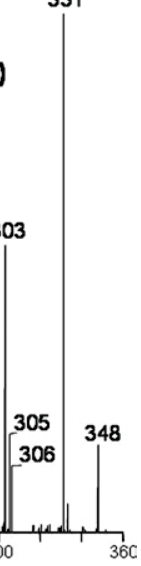

Figure 4. LC-MS/MS of sample obtained by reaction between IQ and dG: (a) reconstructed ion current chromatogram of $\mathrm{m} / \mathrm{z} 464$ losing a deoxyribose, and $\mathrm{MS}^{3}$ spectra of (b) dG-C8-IQ, (c) dG-N²-IQ, and (d) dG-N7-IQ.

Table 2. Accurate mass data from HRMS ${ }^{n}$ analyses of dG-C8-IQ

\begin{tabular}{|c|c|c|c|c|}
\hline Measured mass & Attribution & Molecular formula & Theoretical mass & Delta (ppm) \\
\hline 464.17904 & {$[\mathrm{dGIQ}+\mathrm{H}]^{+}$} & $\mathrm{C}_{21} \mathrm{H}_{22} \mathrm{O}_{4} \mathrm{~N}_{9}$ & 464.17948 & 0.94 \\
\hline 348.13222 & {$[\mathrm{GIO}+\mathrm{H}]^{+}$} & $\mathrm{C}_{16} \mathrm{H}_{14} \mathrm{ON}_{9}$ & 348.13213 & 0.26 \\
\hline \multirow[t]{2}{*}{331.10564} & $348-\mathrm{NH}_{3}$ & $\mathrm{C}_{16} \mathrm{H}_{11} \mathrm{ON}_{8}$ & 331.10558 & 0.18 \\
\hline & $348-\mathrm{OH}$ & $\mathrm{C}_{16} \mathrm{H}_{13} \mathrm{~N}_{9}$ & 331.12939 & 71.73 \\
\hline \multirow[t]{3}{*}{306.11031} & $348-\mathrm{CH}_{2} \mathrm{~N}_{2}$ & $\mathrm{C}_{15} \mathrm{H}_{12} \mathrm{ON}_{7}$ & 306.11033 & 0.07 \\
\hline & $348-\mathrm{C}_{2} \mathrm{H}_{2} \mathrm{O}$ & $\mathrm{C}_{14} \mathrm{H}_{12} \mathrm{~N}_{9}$ & 306.12157 & 36.77 \\
\hline & $348-\mathrm{C}_{2} \mathrm{H}_{4} \mathrm{~N}$ & $\mathrm{C}_{14} \mathrm{H}_{10} \mathrm{ON}_{8}$ & 306.09776 & 41.01 \\
\hline \multirow[t]{4}{*}{305.12631} & $348-\mathrm{CHON}$ & $\mathrm{C}_{15} \mathrm{H}_{13} \mathrm{~N}_{8}$ & 305.12632 & 0.03 \\
\hline & $348-\mathrm{C}_{2} \mathrm{H}_{3} \mathrm{O}$ & $\mathrm{C}_{14} \mathrm{H}_{11} \mathrm{~N}_{9}$ & 305.11374 & 41.19 \\
\hline & $348-\mathrm{CH}_{3} \mathrm{~N}_{2}$ & $\mathrm{C}_{15} \mathrm{H}_{11} \mathrm{ON}_{7}$ & 305.10251 & 78.01 \\
\hline & $348-\mathrm{C}_{2} \mathrm{H}_{5} \mathrm{~N}$ & $\mathrm{C}_{14} \mathrm{H}_{9} \mathrm{ON}_{8}$ & 305.08993 & 119.24 \\
\hline \multirow[t]{3}{*}{303.11076} & $348-\mathrm{CH}_{3} \mathrm{ON}$ & $\mathrm{C}_{15} \mathrm{H}_{11} \mathrm{~N}_{8}$ & 303.11067 & 0.30 \\
\hline & $348-\mathrm{CH}_{5} \mathrm{~N}_{2}$ & $\mathrm{C}_{15} \mathrm{H}_{9} \mathrm{ON}_{7}$ & 303.08686 & 78.86 \\
\hline & $348-\mathrm{C}_{2} \mathrm{H}_{7} \mathrm{~N}$ & $\mathrm{C}_{14} \mathrm{H}_{7} \mathrm{ON}_{8}$ & 303.07428 & 120.36 \\
\hline 278.11541 & $348-\mathrm{C}_{2} \mathrm{H}_{2} \mathrm{ON}_{2}$ & $\mathrm{C}_{14} \mathrm{H}_{12} \mathrm{~N}_{7}$ & 278.11542 & 0.04 \\
\hline 276.09991 & $348-\mathrm{C}_{2} \mathrm{H}_{4} \mathrm{ON}_{2}$ & $\mathrm{C}_{14} \mathrm{H}_{10} \mathrm{~N}_{7}$ & 276.09977 & 0.51 \\
\hline 251.10453 & & $\mathrm{C}_{13} \mathrm{H}_{11} \mathrm{~N}_{6}$ & 251.10452 & 0.04 \\
\hline 224.09348 & & $\mathrm{C}_{12} \mathrm{H}_{10} \mathrm{~N}_{5}$ & 224.09362 & 0.62 \\
\hline 197.08256 & & $\mathrm{C}_{11} \mathrm{H}_{9} \mathrm{~N}_{4}$ & 197.08272 & 0.81 \\
\hline 184.08723 & & $\mathrm{C}_{11} \mathrm{H}_{10} \mathrm{~N}_{3}$ & 184.08747 & 1.30 \\
\hline
\end{tabular}


(a)

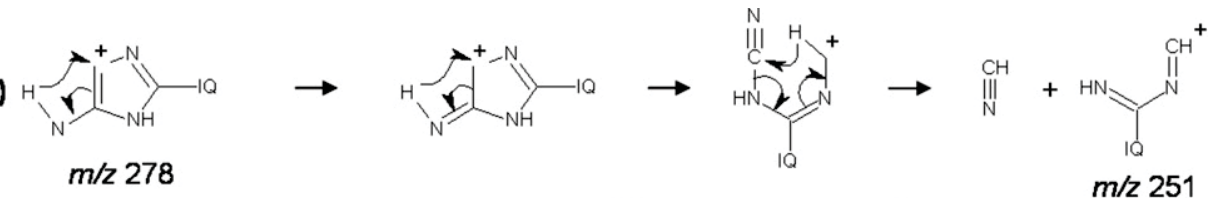

$m / 2278$
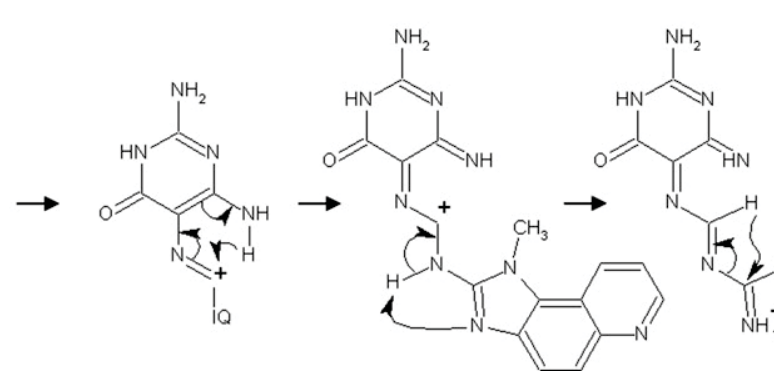

$m / z 251$

(b)

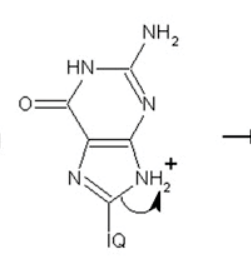

Scheme 2 dG-C8-IQ

Loss of the deoxyribose moiety from this precursor ion was also confirmed by accurate mass measurement of the $m / z 348$ fragment ion produced after isolation and excitation of the $\mathrm{m} / \mathrm{z} 464$ precursor ion (Table 2). The $\mathrm{MS}^{3}$ spectrum of the [GIQ $\left.+\mathrm{H}\right]^{+}$precursor ion at $\mathrm{m} / \mathrm{z}$ 348 presented in Figure $4 \mathrm{~b}$ displays the same fragmentation pathways as $\mathrm{dG}-\mathrm{C} 8-\mathrm{PhIP}$ already discussed in the first part of this paper. Indeed, $m / z$ 331, 306, and 305 fragment ions can be unambiguously attributed to the elimination of $\mathrm{NH}_{3}, \mathrm{CH}_{2} \mathrm{~N}_{2}$, and $\mathrm{CHNO}$, respectively, with the support of the accurate mass determinations presented in Table 2. For example, considering the structure of dG-IQ adducts, possible losses of $\mathrm{CH}_{3} \mathrm{CO}$, $\mathrm{CH}_{3} \mathrm{~N}_{2}$, or $\mathrm{C}_{2} \mathrm{H}_{5} \mathrm{~N}$ could yield isobaric fragment ions at $\mathrm{m} / \mathrm{z} 305$. These fragmentation pathways could be easily ruled out because calculated masses for the corresponding isobaric fragment ions and reported in Table 2 always yield values very far from the measured $\mathrm{m} / \mathrm{z}$ ratio $(>30 \mathrm{ppm})$. Similarly, results reported in Table 2 for the $m / z 303,278$, and 276 fragment ions fit very well losses of $\mathrm{CH}_{3} \mathrm{ON}, \mathrm{C}_{2} \mathrm{H}_{2} \mathrm{ON}_{2}$, and $\mathrm{C}_{2} \mathrm{H}_{4} \mathrm{ON}_{2}$, respectively, from the $m / z 348$ precursor ion (delta $<1 \mathrm{ppm}$ ). According to the same pathways as for dG-C8-PhIP, the $\mathrm{m} / \mathrm{z} 303$ ion finds its origin in the consecutive loss of $\mathrm{CO}$ from the $m / z 331$ ion, as confirmed by $\mathrm{MS}^{4}$ (data not shown). An additional sequential $\mathrm{MS}^{5}$ experiment carried out on the $\left[\mathrm{GIQ}+\mathrm{H}-\mathrm{CH}_{3} \mathrm{ON}\right]^{+} \mathrm{m} / z 303$ ion yielded the $m / z 276$ fragment ion, thus confirming that this latter originated in the consecutive loss of $\mathrm{HCN}$ from the selected $m / z 303$ precursor ion. Similarly, the occurrence of the $m / z 278$ ion on the low-resolution $\mathrm{MS}^{4}$ spectrum of the $\mathrm{m} / \mathrm{z} 306$ ion was in agreement with a loss of CO from this latter species (data not shown). It should also be noted that the spectrum presented in Figure $4 \mathrm{~b}$ displays a fragment ion at $m / z 251$, whereas no signal is present at $m / z 236$. The $\mathrm{MS}^{4}$ spectrum of the $m / z 278$ ion also exhibited a fragment ion at $m / z 251$ and no signal at $m / z 236$ (data not shown). This means that, although the $\left[\mathrm{GIQ}+\mathrm{H}-\mathrm{CH}_{2} \mathrm{~N}_{2}-\mathrm{CO}^{+} \mathrm{m} / \mathrm{z} 278\right.$ fragment ion likely displays the same kind of structure as the $\left[\mathrm{GPhIP}+\mathrm{H}-\mathrm{CH}_{2} \mathrm{~N}_{2}-\mathrm{CO}\right]^{+} \mathrm{m} / \mathrm{z} 304$ fragment ion of $[\mathrm{GPhIP}+\mathrm{H}]^{+}$(see Scheme 1a) according to its molecular formula (Table 2), its behavior toward collisional excitation was different because it did not undergo a consecutive loss of $\mathrm{CH}_{2} \mathrm{~N}_{2}$. Alternatively, the $\mathrm{m} / \mathrm{z} 251$ fragment ion exhibits a molecular formula corresponding to IQ with an additional $\mathrm{C}_{2} \mathrm{H}_{2} \mathrm{~N}_{2}$ (Table 2). This shows that the $m / z 278$ undergoes HCN elimination, which can be rationalized according to Scheme $2 \mathbf{a}$. This feature indicates that the nature of the alkylating HAA can influence the fragmentation pathway involving the $\mathrm{dG}$ moiety of the adduct formed. The $\mathrm{m} / \mathrm{z} 224$ fragment ion occurred with a relative intensity of about $15 \%$ on the $\mathrm{MS}^{3}$ spectrum acquired from the $\mathrm{m} / \mathrm{z} 348$ ion. Its accurate $m / z$ ratio measured at 224.09348 (elemental composition, $\mathrm{C}_{12} \mathrm{H}_{10} \mathrm{~N}_{5}$ ), indicated that its structure was similar to that of the $m / z 250$ fragment ion of [G-C8-PhIP + $\mathrm{H}^{+}$(see Scheme 1b) and that dG was linked to IQ via its C8 atom. The most probable molecular formula of the $m / z 197$ fragment ion presented in Table 2 showed that it corresponded to the IQ moiety. Finally, the molecular formula of the $m / z 184$ ion (Table 2) is in good agreement with a structure involving IQ without its primary amine function (Scheme $\mathbf{2 b}$ ) and is of particular interest because it can be considered as diagnostic of the linkage of IQ to $\mathrm{dG}$ via its exocyclic primary amine function.

Taking into account its formation yield, this IQ adduct could also be analyzed by NMR to confirm the atom of IQ involved in the covalent bond with the C8

\begin{tabular}{cc}
\hline Proton & $\delta \mathrm{H}(\mathrm{ppm})$ \\
\hline $\mathrm{N}-\mathrm{CH} 3$ & 4.34 \\
$\mathrm{H} 4$ & 8.16 \\
$\mathrm{H} 5$ & 8.11 \\
$\mathrm{H} 7$ & 9.03 \\
$\mathrm{H} 8$ & 7.75 \\
$\mathrm{H} 9$ & 8.94 \\
\hline
\end{tabular}

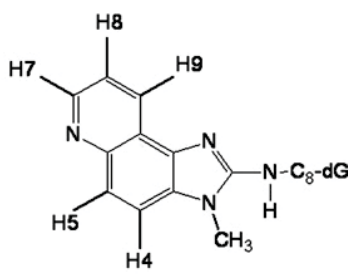

Figure 5. Chemical shifts of dG-C8-IQ obtained by proton NMR spectrometry. 
Table 3. Accurate mass data from HRMS ${ }^{\mathrm{n}}$ analyses of dG-N ${ }^{2}-\mathrm{IQ}$

\begin{tabular}{ccccc}
\hline Measured mass & Attribution & Molecular formula & Theoretical mass & Delta (ppm) \\
\hline \hline 464.17933 & {$[\mathrm{dGIQ}+\mathrm{H}]^{+}$} & $\mathrm{C}_{21} \mathrm{H}_{22} \mathrm{O}_{4} \mathrm{~N}_{9}$ & 464.17948 & 0.31 \\
348.13215 & {$[\mathrm{GIQ}+\mathrm{H}]^{+}$} & $\mathrm{C}_{16} \mathrm{H}_{14} \mathrm{ON}_{9}$ & 348.13213 & 0.06 \\
331.10553 & $348-\mathrm{NH}_{3}$ & $\mathrm{C}_{16} \mathrm{H}_{11} \mathrm{ON}_{8}$ & 331.10558 & 0.15 \\
305.12642 & $348-\mathrm{CHON}$ & $\mathrm{C}_{15} \mathrm{H}_{13} \mathrm{~N}_{8}$ & 305.12632 & 0.33 \\
265.08372 & & $\mathrm{C}_{13} \mathrm{H}_{9} \mathrm{ON}_{6}$ & 265.08378 & 0.23 \\
239.10435 & & $\mathrm{C}_{12} \mathrm{H}_{11} \mathrm{~N}_{6}$ & 239.10452 & 0.71 \\
214.10907 & & $\mathrm{C}_{11} \mathrm{H}_{12} \mathrm{~N}_{5}$ & 214.10927 & 0.93 \\
\hline
\end{tabular}

carbon atom of dG. The chemical shifts observed for IQ protons are reported in Figure 5. These data are in good agreement with published results [14], and confirm that the primary amine function of IQ is bonded to the guanine moiety.

The elemental compositions of the various ions observed on the MS ${ }^{\mathrm{n}}$ spectra of the compound eluting at $\mathrm{RT}=12.0 \mathrm{~min}$ are reported in Table 3. The molecular formula of the $\mathrm{m} / \mathrm{z} 464$ ion is in agreement (0.31 ppm) with the dG-IQ adduct and that of the $\mathrm{m} / \mathrm{z} 348$ fragment ion fits the loss of deoxyribose within $0.06 \mathrm{ppm}$. From the $\mathrm{MS}^{3}$ spectrum reported in Figure 4c and the accurate mass measurements of its related fragment ions, apparently the $m / z 331$ ion is the result of a loss of $\mathrm{NH}_{3}$. In contrast to dG-C8-IQ, no abundant loss of $42 \mathrm{u}$ leading to the $\mathrm{m} / \mathrm{z} 306$ fragment ion is observed in Figure $4 \mathrm{c}$, indicating that the elimination of $\mathrm{CH}_{2} \mathrm{~N}_{2}$ from the pyrimidinone moiety of $\mathrm{dG}$ is unfavorable. According to its exact mass (Table 3 ), the $m / z 305$ fragment ion results from a loss of CHON from the $\mathrm{m} / \mathrm{z} 348$ precursor ion, which suggests that the dG-IQ bond does not involve the N1 nitrogen atom or the $\mathrm{O} 6$ oxygen atom of dG. Three fragment ions provide more information on the dG-HAA linking site: the $m / z 265,239$, and 214 fragments ions. According to Table $3, \mathrm{C}_{13} \mathrm{H}_{9} \mathrm{ON}_{6}$ is the most probable molecular formula of the $\mathrm{m} / \mathrm{z} 265$ fragment ion. This implies that this ion contains one oxygen atom and could correspond to the structure proposed in Scheme 3a, indicating that IQ is not linked to the imidazole moiety of dG. A structure can also be proposed for the $\mathrm{m} / \mathrm{z} 239$ fragment ion from its molecular formula (Table 3) and is reported in Scheme $\mathbf{3 b}$. The accurate mass measurement of the $\mathrm{m} / \mathrm{z} 214$ fragment ion is consistent with a $\mathrm{C}_{11} \mathrm{H}_{12} \mathrm{~N}_{5}$ elemental composition corresponding to the IQ moiety bearing an additional primary amine function as presented in Scheme 3c. This shows that IQ is linked to the exocyclic $\mathrm{N}^{2}$ nitrogen atom of dG. Although diagnostic ions provided evidence of the involvement of the $\mathrm{N}^{2}$ nitrogen atom of $\mathrm{dG}$ in the bonding with IQ, no information was available for identifying the atom of IQ involved into the covalent bond with the adduct. However, formation of the $\mathrm{dG}-\mathrm{N}^{2}-\mathrm{IQ}$ adduct has already been reported with the structure indicated in Figure 4c. The formation of such an adduct was explained considering a covalent bond formation between the $\mathrm{N}^{2}$ nitrogen atom of $\mathrm{dG}$ and the C5 carbon atom of IQ after charge delocalization of the initial arylnitrenium ion [14].

A third dG-IQ adduct was also detected at RT $=15.9$ min (Figure 4a) and was also submitted to LC-MS ${ }^{\text {n }}$ analyses, yielding the $\mathrm{MS}^{3}$ spectrum presented in Figure $4 \mathrm{~d}$. The accurate mass for the $[\mathrm{M}+\mathrm{H}]^{+}$ion of this adduct could be measured at $\mathrm{m} / \mathrm{z} 464.17848$ (theoretical mass for $\mathrm{C}_{21} \mathrm{H}_{22} \mathrm{O}_{4} \mathrm{~N}_{9}$ : 464.17948). This corresponds to (a)

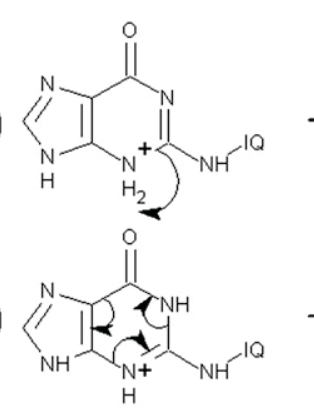

(c)<smiles></smiles>
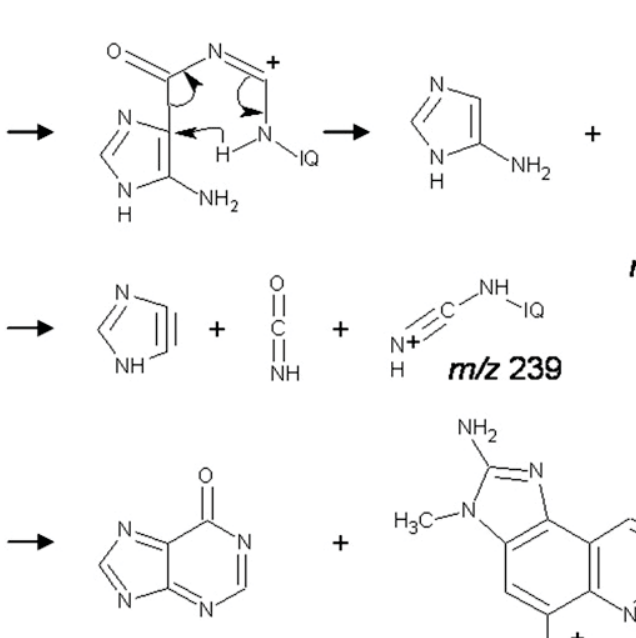
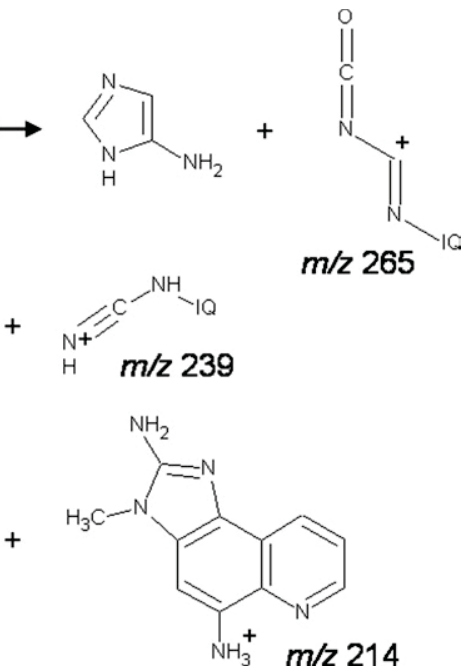

Scheme 3. Formation mechanisms proposed for fragment ions observed in the $\mathrm{MS}^{3}$ spectrum of dG-N ${ }^{2}-\mathrm{IQ}$. 
(a)

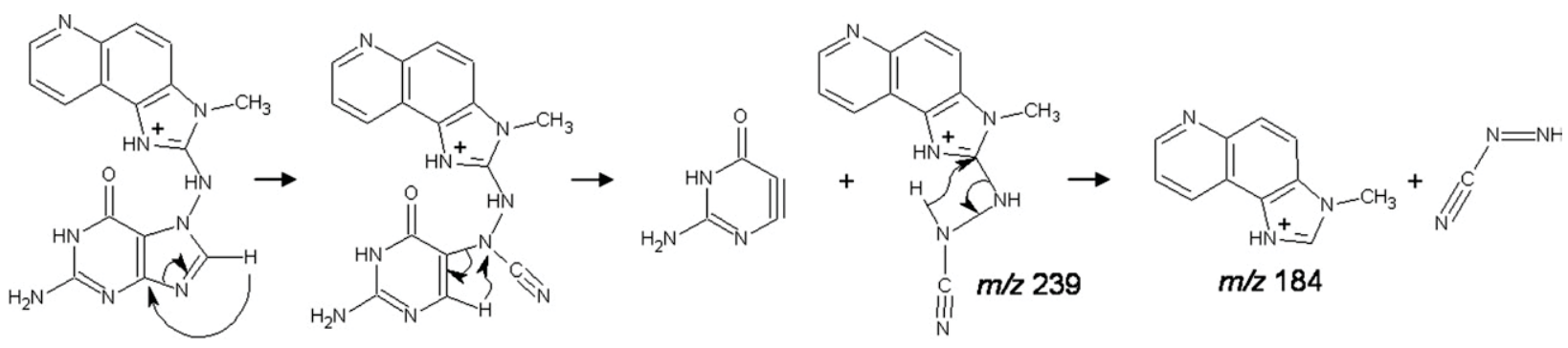

(b)

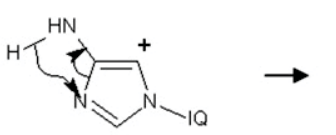

$m / 2278$

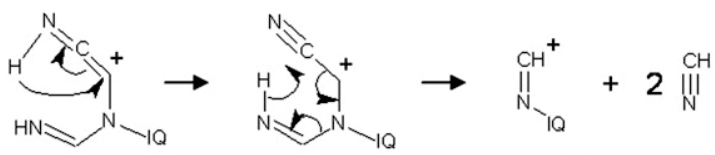

$m / 2224$

Scheme 4. Formation mechanisms proposed for fragment ions observed in the $\mathrm{MS}^{3}$ spectrum of dG-N7-IQ.

an experimental error of 2.15 ppm error allowing confirmation of the elemental composition of this species with good confidence. However, although this adduct formed could be analyzed using the LTQ linear ion trap, which is a part of the LTQ-Orbitrap device, the transfer process of ions toward the Orbitrap via the so-called C-trap device was not effective enough to allow $\mathrm{MS}^{\mathrm{n}}$ accurate mass measurements using the Orbitrap, whatever the experimental operating parameters investigated for this purpose. Nevertheless, the low-resolution $\mathrm{MS}^{3}$ spectrum of this adduct displayed in Figure $4 \mathrm{~d}$ presents some similarity with the $\mathrm{MS}^{3}$ spectra of dG-C8-IQ and dG-N ${ }^{2}-\mathrm{IQ}$ adducts. Considering the previously discussed mass spectra (Figures 2c and $4 \mathrm{~b}), m / z 331,306,305,303,278$, and 276 fragment ions can reasonably find their origin in the same fragmentation pathways as those proposed for dG-C8-PhIP and dG-C8-IQ. The occurrence of these fragment ions indicates that all eliminations concerning the sixmembered ring of $\mathrm{dG}$ could also occur on this adduct and, thus, that the alkylation must have occurred on the imidazole ring of dG. After a closer look at the structure of $\mathrm{dG}$, the only possibility other than the $\mathrm{C} 8$ position to covalently bind to an electrophilic species via its imidazole moiety is the N7 nitrogen atom. Considering such a structure, although no accurate mass determination could be achieved on the $\mathrm{MS}^{3}$ product ions for this adduct, the $\mathrm{m} / \mathrm{z} 239$ fragment ion (present on the $\mathrm{MS}^{3}$ spectra of both dG-N2-IQ and dG-N7-IQ, Figure 4c and d) and the $m / z 224$ fragment ion (appearing on the $\mathrm{MS}^{3}$ spectra of both dG-C8-IQ and dG-N7-IQ, Figure $4 \mathrm{~b}$ and d) can reasonably correspond to the structures pro- posed in Scheme $4 \mathbf{a}$ and $\mathbf{b}$, respectively. Finally, the $m / z$ 184 fragment ion (Scheme 4a) likely displays the same structure as for dG-C8-IQ (see Figure $4 \mathrm{~b}$ and Scheme $2 \mathrm{~b})$, and provides evidence for the involvement of the exocyclic primary amine function of IQ in the covalent bonding with $\mathrm{dG}$.

The structure of this dG-N7-IQ adduct deduced from ion trap $\mathrm{MS}^{3}$ experiments could not be confirmed by NMR spectrometry due to the very low amounts available. Nevertheless, the N7 position of guanine is the target of genotoxic compounds because the N7 atom is described as the most nucleophilic site of $\mathrm{dG}$ and therefore should be a favored position for electrophilic derivative attacks [25]. Generally, dG-N7 adducts are not stable and rapidly undergo decomposition reactions, mainly depurination [26, 27], which have not been observed during our work. On the other hand, dG-N7 adducts have already been synthesized with arylamines and were stable enough to be characterized by NMR [28] and a linkage of PhIP with the N7 atom of $\mathrm{dG}$ has also been proposed for a minor adduct detected in vivo in rat [24]. Besides, dG-C8 adducts can also find their origin (at least partially) in a rearrangement process occurring on initial dG-N7 adducts, in particular when a nitrenium ion represents the electrophilic species leading to adduct formation [29-31]. The characterization of a dG-N7-IQ adduct in this work provides new information to clarify the formation mechanism of the dG-C8-IQ adduct, considering the generation of dG-N7 in a first step, followed by a possible rearrangement leading to the $\mathrm{dG}-\mathrm{C} 8$ adduct. Therefore, the rearrangement mechanism reported in Scheme 5 can be<smiles>Cn1cnc2c(=O)[nH]c(N)nc21</smiles><smiles></smiles>

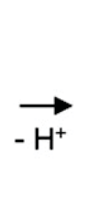

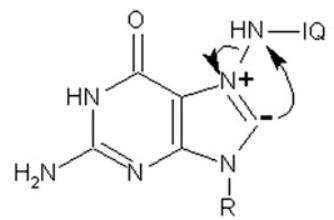<smiles>[R]n1c(NCl)nc2c(=O)[nH]c(N)nc21</smiles>

Scheme 5. Rearrangement mechanism proposed for the formation of the dG-C8-IQ adduct from an initial dG-N7-IQ adduct. 
Table 4. Accurate mass data from $\mathrm{HRMS}^{\mathrm{n}}$ analyses of $\mathrm{dA}-\mathrm{N}^{6}-\mathrm{IQ}$

\begin{tabular}{|c|c|c|c|c|}
\hline Measured mass & Attribution & Molecular formula & Theoretical mass & Delta (ppm) \\
\hline 448.18439 & {$[\mathrm{dAIO}+\mathrm{H}]^{+}$} & $\mathrm{C}_{21} \mathrm{H}_{22} \mathrm{O}_{3} \mathrm{~N}_{9}$ & 448.18456 & 0.38 \\
\hline 332.13725 & {$[\mathrm{AlQ}+\mathrm{H}]^{+}$} & $\mathrm{C}_{16} \mathrm{H}_{14} \mathrm{~N}_{9}$ & 332.13722 & 0.10 \\
\hline 317.11376 & $332-\mathrm{CH}_{3}$ & $\mathrm{C}_{15} \mathrm{H}_{11} \mathrm{~N}_{9}$ & 317.11374 & 0.06 \\
\hline 315.11081 & $332-\mathrm{NH}_{3}$ & $\mathrm{C}_{16} \mathrm{H}_{11} \mathrm{~N}_{8}$ & 315.11067 & 0.44 \\
\hline 305.12640 & $332-\mathrm{HCN}$ & $\mathrm{C}_{15} \mathrm{H}_{13} \mathrm{~N}_{8}$ & 305.12632 & 0.26 \\
\hline 239.10455 & & $\mathrm{C}_{12} \mathrm{H}_{11} \mathrm{~N}_{6}$ & 239.10452 & 0.13 \\
\hline 224.09351 & & $\mathrm{C}_{12} \mathrm{H}_{10} \mathrm{~N}_{5}$ & 224.09362 & 0.49 \\
\hline \multirow[t]{3}{*}{213.10131} & & $\mathrm{C}_{11} \mathrm{H}_{11} \mathrm{~N}_{5}$ & 213.10144 & 0.61 \\
\hline & & $\mathrm{C}_{10} \mathrm{H}_{9} \mathrm{~N}_{6}$ & 213.08887 & 58.38 \\
\hline & & $\mathrm{C}_{12} \mathrm{H}_{13} \mathrm{~N}_{4}$ & 213.11402 & 59.64 \\
\hline
\end{tabular}

reasonably proposed for the formation of both dGN7-IQ and dG-C8-IQ, based on the mechanism initially suggested by Humphreys et al. for the C8 alkylation of guanine by activated arylamines [28]. In addition, this mechanism represents the only way to explain the formation of a dG-N7 adduct without considering the destabilization of the glycosidic bond leading to a depurination process. It should be noted, however, that the dG-C8-IQ adduct may also find its origin in the reactivity of the guanine $\mathrm{C} 8$ atom itself.

The reaction of IQ with $\mathrm{dA}$ also led to the formation of an unknown adduct. The resulting chromatogram showed the occurrence of a weak peak with an accurate mass measured at $\mathrm{m} / \mathrm{z} 448.18439$ (Table 4), which is in agreement with the elemental composition of the dA-IQ adduct. As for $\mathrm{dG}$ adducts, the $[\mathrm{dAIQ}+\mathrm{H}]^{+}$precursor ion also underwent a loss of deoxyribose when submitted to resonant excitation into the ion trap device as indicated by the accurate mass measurement of the $\mathrm{m} / \mathrm{z}$ 332 fragment ion (Table 4). Figure 6 shows the MS ${ }^{3}$ spectrum of the $\mathrm{m} / \mathrm{z} 332$ ion resulting from the decomposition of the $\mathrm{m} / \mathrm{z} 448$ ion in a $\mathrm{MS}^{2}$ step, and the corresponding accurate mass measurements of the most abundant fragment ions are reported in Table 4 . The loss of $\cdot \mathrm{CH}_{3}$ from the IQ moiety of the selected $\mathrm{m} / \mathrm{z} 332$ ion explains the occurrence of the $\mathrm{m} / \mathrm{z} 317$ fragment ion according to data reported in Table 4 . By the same way, $\mathrm{m} / \mathrm{z} 315$ and 305 fragment ions could be attributed to the elimination of $\mathrm{NH}_{3}$ and $\mathrm{HCN}$, respectively (see Table 4). The peak observed at $\mathrm{m} / \mathrm{z} 239$ is more informative because it allows precise determination of the dA-IQ adduct structure. Its elemental composition fits $\mathrm{C}_{12} \mathrm{H}_{11} \mathrm{~N}_{6}$ with an error of only $0.13 \mathrm{ppm}$. This corresponds to the structure proposed in Scheme 6a, which involves IQ and an additional $\mathrm{CHN}_{2}$ as for dG-N ${ }^{2}$-IQ. Similarly, determination of the elemental composition of the $\mathrm{m} / \mathrm{z} 224$ fragment ion from [AIQ + $\mathrm{H}]^{+}$(Table 4) allows us to propose a structure corresponding to IQ with an additional HCN (Scheme 6b). Finally, accurate mass measurement of the $\mathrm{m} / \mathrm{z} 213$ fragment ion (Table 4) gave $\mathrm{C}_{11} \mathrm{H}_{11} \mathrm{~N}_{5}$ as the most probable molecular formula ( $0.61 \mathrm{ppm}$ error). Actually, taking into account the nitrogen rule, the occurrence of this ion could be explained only by considering a radical ion involving IQ and an additional primary amine function (Scheme $\mathbf{6 c}$ ), whereas a protonated form at $m / z 214$ would have seemed more plausible. However, Table 4 indicates that theoretical masses calculated for $m / z 213$ isobaric ions with even numbers of nitrogen atoms (therefore corresponding to protonated ions) gave values distant from the measured mass by more than $50 \mathrm{ppm}$. Therefore, the structure of the $\mathrm{m} / \mathrm{z} 213$ fragment ion indicates that IQ is linked to $\mathrm{dA}$ via the extracyclic primary amine function of the nucleobase. In this case, again, the accurate mass measurements of the various fragment ions produced by $\mathrm{MS}^{3}$ experiments on the LTQ-Orbitrap instrument allowed their unambiguous assignment, and thus the identification of this new adduct as dA-N $\mathrm{N}^{6}-\mathrm{IQ}$.

The $\mathrm{N}^{6}$ nitrogen atom of adenine has already been described as a target for genotoxic agents [32], such as estrogens [27], polycyclic aromatic hydrocarbons [33, 34], or aristolochic acid [35]. However, no diagnostic information allowing the determination of the IQ atom involved in the bonding with adenine could be obtained by multi-step $\mathrm{MS}^{3}$ experiments. The loss of $\mathrm{NH}_{3}$ leading to formation of the $\mathrm{m} / \mathrm{z} 315$ fragment ion, which

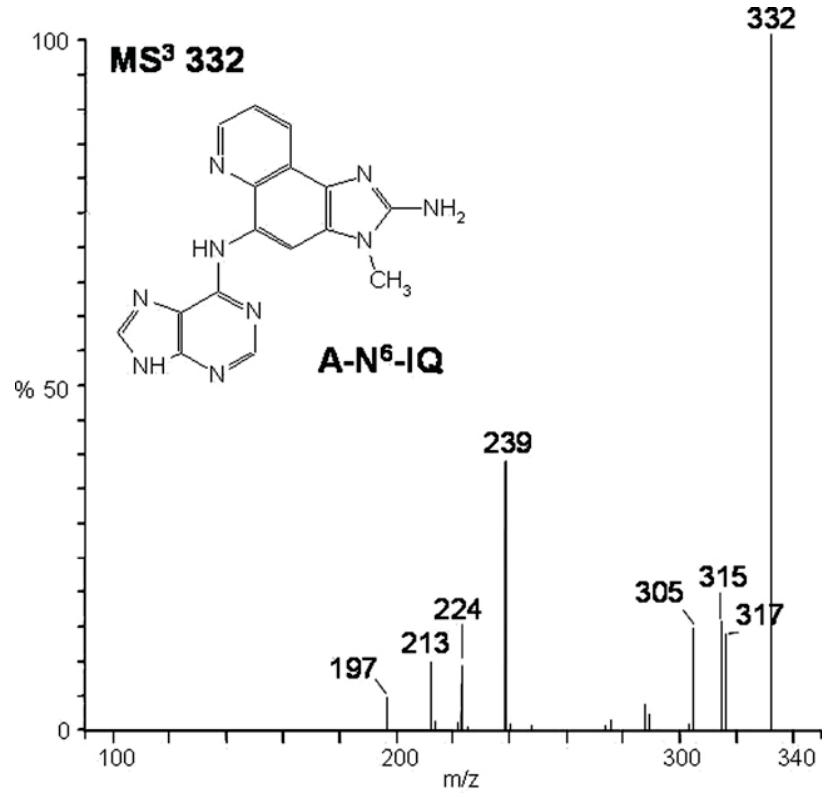

Figure 6. $\mathrm{MS}^{3}$ spectrum of $\mathrm{dA}-\mathrm{N}^{6}-\mathrm{IQ}$. 
(a)

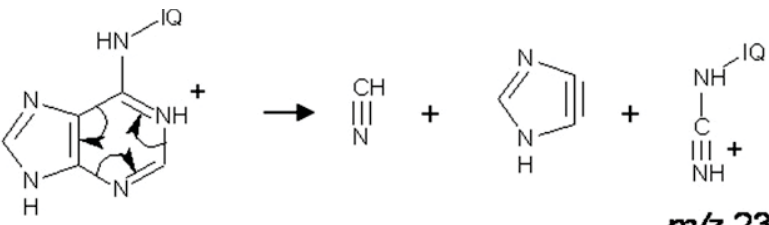

(b)<smiles>O=[N+]([O-])[N+]1=CN=C2NC=NC2C1=NO</smiles>

(c)<smiles>C[N+](O)(O)c1ncnc2[nH]cnc12</smiles>

$m / z 239$

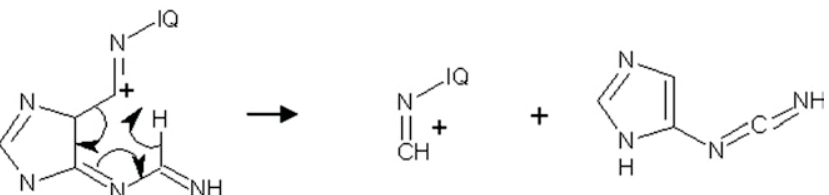

$m / z 224$

Scheme 6. Formation mechanisms proposed for fragment ions observed in the $\mathrm{MS}^{3}$ spectrum of dA-N $-\mathrm{IQ}$.

may come from a primary amine function, indicates only that the primary amine function of IQ is not involved in the linking of $\mathrm{dA}$ and IQ. Thus, by analogy with dG-N ${ }^{2}$-IQ adduct, which also involves a primary amine function of the deoxynucleoside, we propose that the bond between $\mathrm{dA}-\mathrm{N}^{6}$ and IQ is also formed with the C5 aromatic carbon atom of IQ by a charge delocalization of the arylnitrenium ion [14].

No detectable adducts were found from reactions involving $N$-hydroxy-IQ and dC or dT. Finally, a reaction involving $N$-hydroxy-IQ and an equimolar mixture of the four deoxynucleosides was achieved to check potential competitive effects of deoxynucleosides between each other. All four of the dG-C8, N ${ }^{2}$ and N7-IQ and $\mathrm{dA}-\mathrm{N}^{6}-\mathrm{IQ}$ adducts were obtained and their relative proportions were in agreement with the syntheses conducted using single deoxynucleosides, suggesting that the formation of IQ adducts was not affected by competitive or synergistic effects.

\section{Conclusions}

A systematic study has been conducted on the reactivity of two HAAs toward deoxynucleosides, on the basis of chemical reactions involving the four DNA bases and chemically activated HAAs: NHOH-IQ and $\mathrm{NHOH}-\mathrm{PhIP}$. The structural characterization of the adducts formed was improved by using modern highresolution $\mathrm{MS}^{\mathrm{n}}$ methods, in particular accurate mass measurements of fragment ions observed on $\mathrm{MS}^{3}$ spectra, allowing determination of their elemental composition. This clearly shows the usefulness of exact mass data for supporting the overall fragmentation patterns, and this, combined with $\mathrm{MS}^{\mathrm{n}}$ experiments, provides new information for already known adducts [24] as well as for new adducts detected in this work.

Besides the already known dG-C8-PhIP, dG-C8-IQ, and dG-N ${ }^{2}-\mathrm{IQ}$, two new adducts were identified. The first one (dG-N7-IQ) is quite unusual because its formation implies an initial hydrazo linkage between the HAA and the N7 atom of guanine. A mechanism is proposed for the rearrangement of this particular adduct into the dG-C8-IQ adduct. Although a similar dG-N7 adduct has recently been hypothesized for PhIP [24], no such compound was evidenced in our work conducted in vitro with PhIP. A second new adduct has been detected in the reaction between IQ and $\mathrm{dA}-\mathrm{dA}$ $\mathrm{N}^{6}$-IQ. This constitutes the first report on the formation of an adduct between an HAA and a deoxynucleoside other than dG. This new information may contribute to a better understanding of mutations involving $\mathrm{A}$ or $\mathrm{T}$ nucleobases observed in vivo [36], which cannot be explained by adduct formation with dG.

Extensive high-resolution data are provided in this work, which will be useful for the MS detection of such adducts based on diagnostic fragment ions in forthcoming further studies on the formation of HAA-DNA adducts conducted in vitro or in vivo.

\section{Acknowledgments}

This work was supported by a grant from the Institut National Polytechnique de Toulouse, France. The authors thank A. Carrere for her valuable contribution to this study, P. Vouros and J. Glick (Northeastern University, Boston, MA, USA) for kindly providing standard dG-C8-PhIP used for adjusting their synthesis protocol of PhIP adduct. They also thank S. Alves, D. Lesage, and J.-C. Tabet (University Pierre \& Marie Curie, Paris, France) for helpful discussions around the LTQ-Orbitrap mass spectrometer.

\section{References}

1. Garner, R. C. The Role of DNA Adducts in Chemical Carcinogenesis. Mutat. Res. 1998, 402, 67-75. 
2. Wogan, G. N.; Hecht, S. S.; Felton, J. S.; Conney, A. H.; Loeb, L. A. Environmental and Chemical Carcinogenesis. Semin. Cancer Biol. 2004, $14,473-486$.

3. Schut, H. A. J.; Snyderwine, E. G. DNA Adducts of Heterocyclic Amine Food Mutagen: Implication for Mutagenesis and Carcinogenesis. Carcinogenesis 1999, 20, 353-368.

4. Snyderwine, E. G.; Venugopal, M.; Yu, M. Mammary Gland Carcinogenesis by Food-derived Heterocyclic Amines and Studies on the Mechanisms of Carcinogenesis of 2-Amino-1-methyl-6-phenylimidazo [4,5-b]pyridine (PhIP). Mutat. Res. 2002, 506-507, 145-152.

5. Zöchling, S.; Murkovic, M. Formation of the Heterocyclic Aromatic Amine PhIP: Identification of Precursors and Intermediates. Food Chem. 2002, 79, 125-134.

6. Murkovic, M. Formation of Heterocyclic Aromatic Amines in Model Systems. J. Chromatogr. B. 2004, 802, 3-10.

7. Skog, K. Problems Associated with the Determination of Heterocyclic Amines in Cooked Foods and Human Exposure. Food Chem. Toxicol. 2002, 40, 1197-1203.

8. Skog, K. I.; Johansson, M. A. E.; Jägerstad, M. I. Carcinogenic Heterocyclic Amines in Model Systems and Cooked Foods: A Review on Formation, Occurrence and Intake. Food Chem. Toxicol. 1998, 36, 879896.

9. Turesky, R. J. Interspecies Metabolism of Heterocyclic Aromatic Amines and the Uncertainties in Extrapolation of Animal Toxicity Data for Human Risk Assessment. Mol. Nutr. Food Res. 2005, 49, 101-117.

10. Novak, M.; Rajagopal, S.; Xu, L.; Kazerani, S.; Toth, K.; Brooks, M.; Nguyen, T.-M. Chemistry of Carcinogenic and Mutagenic Metabolites of Heterocyclic Aromatic Amines. J. Phys. Org. Chem. 2004, 17, 615-624.

11. de Kok, T. M. C. M.; Moonen, H. J. J.; van Delft, J.; van Schooten, F. J. Methodologies for Bulky DNA Adduct Analysis and Biomonitoring of Environmental and Occupational Exposures. J. Chromatogr. B. 2002, 778, 345-355.

12. Koc, H.; Swenberg, J. A. Applications of Mass Spectrometry for Quantification of DNA Adducts. J. Chromatogr. B. 2002, 778, 323-343.

13. Turesky, R. J.; Vouros, P. Formation and Analysis of Heterocyclic Aromatic Amines-DNA Adducts in Vitro and in Vivo. J. Chromatogr. B. 2004, 802, 155-166.

14. Turesky, R. J.; Rossi, S. C.; Welti, D. H.; Lay, J. O.; Kadlubar, F. F. Characterisation of DNA Adducts Formed in Vitro by Reaction of $N$-Hydroxy-2-amino-3-methylimidazo[4,5-flquinoline and $N$-Hydroxy2-amino-3,8-dimethylimidazo[4,5-f]quinoxaline at the C-8 and $\mathrm{N}^{2}$ Atoms of Guanine. Chem. Res. Toxicol. 1992, 5, 479-490.

15. Brown, K.; Guenther, E. A.; Dingley, K. H.; Cosman, M.; Harvey, C. A.; Shields, S. J.; Turteltaub, K. W. Synthesis and Spectroscopic Characterisation ofSite-specific 2-Amino-1-methyl-6-phenylimidazo[4,5-b]pyridine Oligodeoxyribonucleo-tide Adducts. Nucleic Acids Res. 2001, 29, 19511959.

16. Crosbie, S. J.; Murray, S.; Boobis, A. R.; Gooderham, N. J. Mass Spectrometric Detection and Measurement of $N^{2}$-(2'-deoxyguanosin-8-yl)PhIP Adducts in DNA. J. Chromatogr. B. 2000, 744, 55-64.

17. Tanga, M. J.; Bupp, J. E.; Bradford, W. W. Synthesis of Deuterated 2-Amino-1-methyl-6-phenyl-1H-imidazo[4,5-b]pyridine (PhIP) and its N-Hydroxy Derivative. J. Labelled Compd. Radiopharm. 2001, 44, 405-411.

18. Hu, Q.; Noll, R. J.; Hongyan, L.; Makarov, A.; Hardman, M.; Cooks, R. G. The Orbitrap: A New Mass Spectrometer. J. Mass Spectrom. 2005, 40, 430-443.

19. Rindgen, D.; Turesky, R. J.; Vouros, P. Determination of in Vitro Formed DNA Adducts of 2-Amino-1-methyl-6-phenylimidazo[4,5- $b]$ pyridine Using Capillary Liquid Chromatography/Electrospray Ionization/Tandem Mass Spectrometry. Chem. Res. Toxicol. 1995, 8, 1005-1013.

20. Paehler, A.; Richoz, J.; Soglia, J.; Vouros, P.; Turesky, R. J. Analysis and Quantification of DNA Adducts of 2-Amino-3,8-dimethylimidazo[4,5-f] quinoxaline in Liver of Rats by Liquid Chromatography/Electrospray Tandem Mass Spectrometry. Chem. Res. Toxicol. 2002, 15, 551-561.

21. Gangl, E. T.; Turesky, R. J.; Vouros, P. Determination of in Vitro and in Vivo Formed DNA Adducts of 2-Amino-3-methylimidazo[4,5-f]quinoline by Capillary Liquid Chromatography/Microelectrospray Mass Spectrometry. Chem. Res. Toxicol. 1999, 12, 1019-1027.

22. Soglia, J. R.; Turesky, R. J.; Paehler, A.; Vouros, P. Quantification of the Heterocyclic Aromatic Amine-DNA Adduct N-(deoxyguanosin-8-yl)-2amino-3-methylimidazo[4,5-flquinoline in Livers of Rats Using Capillary Liquid Chromatography/Microelectrospray Mass Spectrometry: A Dose-Response Study. Anal. Chem. 2001, 73, 2819-2827.

23. Li, L.; Chiarelli, M. P.; Branco, P. S.; Antunes, A. M.; Marques, M. M. Gonçalves, L. L.; Beland, F. A. Differentiation of Isomeric C8-Substituted Alkylaniline Adducts of Guanine by Electrospray Ionization and Tandem Quadrupole Ion Trap Mass Spectrometry. J. Am. Soc. Mass Spectrom. 2003, 14, 1488-1492.

24. Goodenough, A. K.; Schut, H. A. J.; Turesky, R. J. Novel LC/MS/MS Method for the Characterization and Quantification of 2'-Deoxyguanosine Adducts of the Dietary Carcinogen 2-Amino-1-methyl-6-phenylimidazo [4,5-b]pyridine by 2-D Linear Quadrupole Ion Trap Mass Spectrometry. Chem. Res. Toxicol. 2007, 20, 263-276.

25. Pullman, A.; Pullman, B. Electrostatic Potential of the Nucleic-Acids. $Q$. Rev. Biophys. 1981, 14, 289-380.

26. Gates, K. S.; Nooner, T.; Dutta, S. Biologically Relevant Chemica Reactions of N7-Alkylguanine Residues in DNA. Chem. Res. Toxicol. 2004, 17, 839-856.

27. Jouanin, I.; Debrauwer, L.; Fauglas, G.; Paris, A.; Rathahao, E. Adduction of Catechol Estrogens to Nucleosides. Steroids 2002, 67, 1091-1099.

28. Humphreys, W. G.; Kadlubar, F. F.; Guengerich, F. P. Mechanism of C8 Alkylation of Guanine Residues by Activated Arylamines: Evidence for Initial Adduct Formation at the $\mathrm{N}^{7}$ Position. Proc. Natl. Acad. Sci. U.S.A. 1992, 89, 8278-8282.

29. Kennedy, S. A.; Novak, M.; Kolb, B. A. Reactions of Ester Derivatives of Carcinogenic $\mathrm{N}$-(4-Biphenyl)hydroxylamine and the Corresponding Hydroxamic Acid with Purine Nucleosides. J. Am. Chem. Soc. 1997, 119, 7654-7664.

30. Guengerich, F. P.; Mundkowski, R. G.; Voehler, M.; Kadlubar, F. F. Formation and Reaction of N7-Aminoguanosine and Derivatives. Chem. Res. Toxicol. 1999, 12, 906-916.

31. Kaiya, T.; Fujiwara, T.; Kohda, K. Syntheses and Properties of 1-Methyl3-phenylaminobenzimidazolium Salts, Models of DNA Adducts of N7-Arylaminodeoxyguanosinium Salt. Chem. Res. Toxicol. 2000, 13, 993-1001.

32. Dipple, A. DNA Adducts of Chemical Carcinogens. Carcinogenesis 1995, 16, 437-441.

33. Roberts, K. P.; Lin, C.-H.; Jankowiak, R.; Small, G. J. On-line Identification of Diastereomeric dibenzo[a,l]pyrene Diol Epoxide-Derived Deoxyadenosine Adducts by Capillary Electrophoresis-Fluorescence Linenarrowing and Non-line Narrowing Spectroscopy. J. Chromatogr. A. 1999, 853, 159-170.

34. Khalili, H.; Zhang, F.-J.; Harvey, R. G.; Dipple, A. Mutagenicity of Benzo[ $a]$ pyrene-deoxyadenosine Adducts in a Sequence Context Derived from the p53 Gene. Mutat. Res. 2000, 465, 39-44.

35. Zhou, S.; Koh, H.-L.; Gao, Y.; Gong, Z.-Y.; Lee, E. J. D. Herbal Bioactivation: The Good, the Bad and the Ugly. Life Sci. 2004, 74, 935-968.

36. Kakiuchi, H.; Watanabe, M.; Ushijima, T.; Toyota, M.; Imai, K.; Weisburger, J. H.; Sugimura, T.; Nagao, M. Specific 5'-GGGA-3' $\rightarrow$ 5'GGA-3' Mutation of the Apc Gene in Rat Colon Tumors Induced by 2-Amino-3-methyl-6-phenylimidazo[4,5-b]pyridine. Proc. Natl. Acad. Sci. U.S.A. 1995, 92, 910-914. 